\title{
Target adjustment model and new working capital management performance measure: Evidence from Croatia*
}

\author{
Dina Korent ${ }^{1}$
}

\begin{abstract}
The paper develops a dynamic panel model of target adjustment in order to investigate the determinants of the cash conversion cycle of companies in manufacturing, trade, and information and communication industries in the Republic of Croatia for the period 2008-2015. The emphasis is on examining the significances and the speeds of the adjustment processes of the cash conversion cycles of companies subsamples by industry and size. Due to the adjustment costs, the results show that the observed companies gradually adjust their current cash conversion cycles to the target ones. In addition, these adjustments were slow, which can be explained by the predominance of the adjustment costs over the costs of being in disequilibrium. Moreover, the results of this study indicate that the rate of adjustment varies among companies from different industries and size categories. The differences in market power allow companies to change more easily the components of the cash conversion cycle. As a result, they enable faster convergence to their target levels. Besides the lagged cash conversion cycle, tested potential determinants that significantly affect the cash conversion cycles of Croatian companies in selected industries, although with different robustness, are company size, company growth, return on assets, fixed asset investments, financial leverage and the growth of the real gross domestic product. Finally, the paper presents a new measure for working capital management performance.
\end{abstract}

Key words: working capital management, target adjustment model, determinants, performance measure, Croatia

JEL classification: $G 3$

\footnotetext{
* Received: 25-03-2021; accepted: 28-06-2021

1 PhD, Senior Teaching Assistant/Postdoctoral Researcher, Faculty of Organization and Informatics, Pavlinska 2, 42000 Varaždin, University of Zagreb-Croatia. Scientific affiliation: corporate finance, working capital management, capital budgeting, capital structure, business planning.Phone:+38598160 2295.E-mail:dina.korent@foi.unizg.hr.https://www.foi.unizg. $\mathrm{hr} / \mathrm{hr} /$ djelatnici/dina.korent.
} 


\section{Introduction}

Working capital management in this paper is equated with the management of net operating working capital. More precisely, in the narrow sense, the overall management of net operating working capital is defined as the integrative management of inventories, trade receivables and trade payables. In general, this should strive to achieve balanced, optimal levels of working capital components (Ganesan, 2007), or optimal size, structure and circulation of working capital, which largely contribute to attaining the fundamental goal of the company, i.e. maximizing its present value (Deloof, 2003; Raheman \& Nasr, 2007). Striving to achieve the set goal, companies define and implement a working capital management strategy by observing the importance of working capital management and considering the interdependence of risk and profitability under risk preferences.

The effectiveness and efficiency, i.e., the optimality of working capital management strategies, can be described and evaluated by identifying and quantifying the costs of working capital management and the contribution to the achieved profitability and value of the company. In this context, depending on the relationship between rising costs and declining costs with the level of investment in net operating working capital in the narrower sense, the optimal working capital management strategy in a particular situation may be relatively more aggressive or conservative.

With the intention of evaluating and ex-post determining the optimality of working capital management strategy, in the last twenty years, and potentiated by the economic crisis, there is a noticeable increase in research on the impact of working capital management on profitability and performance, and as a result, research on working capital determinants. The results of both groups of studies demonstrate the existence of gaps and inconsistencies, which suggest that the understanding of how to manage working capital is not explicit and can lead to insolvency and bankruptcy of companies (Palombini \& Nakamura, 2012). Consequently, the fact that one cannot talk about one strategy that is necessarily optimal for all companies, independently of their specifics, and in all time periods, the renewed research interest in the field of working capital management determines the permanent need to examine the impact of working capital management on profitability and performance, and the need to identify key determinants of working capital management. This paper is focused on the development and testing of target adjustment models of working capital management of companies in manufacturing, trade as well as on the information and communication industries registered in the Republic of Croatia for the period 2008-2015. It includes the identification of working capital management determinants with an emphasis on examining the significances and the speeds of the adjustment processes of the working capital management indicators of the observed companies. Additionally, the paper develops a new working capital management performance measure, which, to various 
stakeholders, both internal and external, can enable or improve the evaluation and comparison of companies' working capital management performance.

Based on the defined research problem and the resulting research goals, as well as on the literature review, the set hypotheses are as follows:

H1: Croatian companies in selected industries have target levels of cash conversion cycles and follow the processes of continuous partial adjustment to the achieve them.

H2: Speeds of adjustment to the target cash conversion cycles differ among companies from different industries and size categories.

H3: The determinants that significantly affect the cash conversion cycle of Croatian companies in selected industries are the following internal determinants: lagged cash conversion cycle, company size, company growth, return on assets, fixed asset investments and financial leverage, and growth of real gross domestic product as an external determinant.

The remainder of paper is organized as follows. Chapter 2 provides a theoretical framework, the literature review, and sets out the hypotheses. Chapter 3 presents the analysis methods, followed by Chapter 4, presenting the used empirical data and analysis results. Chapter 5 discusses the results of the empirical analysis. Chapter 6 synthesizes the conclusions of the work and limitations and recommendations for future research.

\section{Theoretical framework, literature review and hypotheses}

Based on the pecking order theory, agency theory and asymmetric information theory, and taking into account the costs and benefits of working capital holding, it is assumed that companies have target levels of working capital management indicators (Lee \& Wu, 1988; Peles \& Schneller, 1989; Baños-Caballero et al., 2009). Furthermore the company's working capital management decisions are assumed to aim at achieving the target levels of working capital management indicators and that these levels are function of determinants of working capital management (Baños-Caballero et al., 2009; Baños-Caballero et al., 2010), of which, unlike on those external, company can influence on those internal.

However, despite the well-founded assumption of the existence of target levels and the rational presumption of the intention of the company to achieve them, the current levels of the relevant indicators are not always equal to the desired levels (Baños-Caballero, et al., 2009). There are several reasons for this. According to Nadiri (1969), companies cannot always accurately and reliably estimate sales and purchases, and that they cannot accurately anticipate changes in monetary policy, 
changes in default rates or bad debts on their trade credits, and the detection and collection of delinquent accounts take time and cause certain costs that can be distributed over time. Peles \& Schneller (1989), also suggest that companies could deviate from the target due to accidental or other temporary shocks, changes in the cost of production factors, or due to improvements in technology.

Further, in situations of disequilibrium between the current and desired, i.e. target levels of working capital management indicators, companies follow the adjustment process in order to reach the latter (Baños-Caballero et al., 2009; Baños-Caballero et al., 2010; Abbadi \& Abbadi, 2013; Kwenda \& Holden, 2014), so this process can also be characterized as a dynamic partial adjustment process. The duration of the disequilibrium between the current and target levels, i.e. the speed of adjustment to the target levels of working capital management indicators depends on the trade-off between adjustment costs and costs of being in disequilibrium, that is it is inversely related to the former and directly to the latter (Baños-Caballero et al., 2009; Baños-Caballero et al., 2010; Abbadi \& Abbadi, 2013; Kwenda \& Holden, 2014). If the costs of being in disequilibrium are higher than the adjustment costs, the company quickly adjusts its working capital management to the target, and vice versa (Kwenda \& Holden, 2014). Peles \& Schneller (1989) thus believe that items of current assets and short-term liabilities are largely under the control of the company, so they are easier to manipulate and can be easily changed, even in the short term. In contrast, Baños-Caballero et al. (2013) do not expect that adjustments to target working capital requirements are immediate, precisely because of the existence of adjustment costs. Companies will adjust their working capital requirements only if the benefits outweigh the costs of reducing deviations from their target levels (Baños-Caballero et al., 2013). Besides, since the target levels, as well as the current ones, are subject to change, the adjustment process usually takes place continuously.

Based on the above, and in accordance with the results of studies conducted by BañosCaballero et al. (2009), Baños-Caballero et al. (2010), Abbadi \& Abbadi (2013), Russo (2013) and Kwenda \& Holden (2014), on the samples of Spanish companies listed on the Spain Stock Exchange for the period 1997-2004, Spanish non-financial corporations for the period 2001-2005, of all industrial companies listed on the Palestine Securities Exchange (PSE) for the period 2004-2011, on 2,000 Spanish companies with less than 250 employees, turnover less or equal to $50 €$ million and total assets less than $43 €$ million for the period 2009 -2011, and on a sample of 92 companies from selected sectors listed on the JSE for the period 2001-2010, respectively, the first hypothesis of this paper was set. The first hypothesis assumes the existence of target levels of the cash conversion cycle and the significance of the dynamic nature of working capital management, i.e.,, specifically, of the processes of continuous partial adjustment to the target levels for companies in manufacturing, trade and information and communication industries in Croatia. 
Considering that changes in the levels of working capital, both target and current, are influenced by numerous determinants of working capital, the speed of adjustment, i.e., changes in working capital, is also determined by same. Consequently, taking into account the internal determinants of working capital, it is expected that the adjustment rate is not the same for all companies. Moreover, widening the horizon to industrial and wider macroeconomic determinants of working capital one can provoke the existence of differences in the adjustment rates of companies from different industries and geographical areas. In the context of the internal determinants of working capital, Baños-Caballero et al. (2013), for example, find that the adjustment rate of companies listed on the Spanish stock exchange for the period 1997-2004 depends on external financial constraints, i.e. access to capital markets, and on their bargaining, i.e., market power. In line with the authors' expectations, the estimated speed of adjustment turned out to be higher for companies with better access to external financing and for companies with greater bargaining power. Namely, companies that have better access to capital markets can more easily modify their investments in trade receivables and inventories, as well as the trade credits received. Similarly, companies with greater market power can more easily modify their working capital needs for two reasons (Hill et al., 2010). First, they can extend the terms of credit received from their suppliers and hold less inventories with less consequences on their relationships with suppliers. Second, companies with greater market power can reduce the terms of trade credit given to their customers without incurring major consequences in terms of declining sales. Following the presented study, the second research hypothesis tests the assumption that the rates, i.e., speeds of adjustment to the target cash conversion cycles differ among companies from different industries and size categories.

Building on the previous, the target levels of working capital, and respecting the dynamic adjustment model, and the current ones, are influenced by numerous internal and external factors, as well as by industry in which the company operates. Existing studies test or identify the following internal determinants of working capital: company size (Moss \& Stine, 1993; Chiou et al., 2006; Kieschnick et al., 2006; Baños-Caballero et al., 2009; Hill et al., 2010; Zariyawati et al., 2010; Gill, 2011; Mongrut et al., 2014; Afrifa \& Padachi, 2016; Haron \& Nomran, 2016; among others), that is, access to the capital market, company growth (Chiou et al., 2006; Kieschnick et al., 2006; Baños-Caballero et al., 2009; Nazir \& Afza, 2009; Baños-Caballero et al., 2010; Hill et al., 2010; Zariyawati et al., 2010; Gill, 2011; Russo, 2013; Wasiuzzaman \& Arumugam, 2013; Haron \& Nomran, 2016; among others), return on assets and contribution margin as indicators of company profitability and performance (Chiou et al., 2006; Nazir \& Afza, 2009; BañosCaballero et al., 2010; Gill, 2011; Russo, 2013; Wasiuzzaman \& Arumugam, 2013; Haron \& Nomran, 2016; among others), investments in fixed (tangible) assets (Fazzari \& Petersen, 1993; Kieschnick et al., 2006; Baños-Caballero et al., 2009; Russo, 2013; Wasiuzzaman \& Arumugam, 2013; Kwenda \& Holden, 2014; 
Afrifa \& Padachi, 2016; among others), financial leverage (Chiou et al., 2006; Baños-Caballero et al., 2009; Nazir \& Afza, 2009; Baños-Caballero et al., 2010; Zariyawati et al., 2010; Gill, 2011; Russo, 2013; Wasiuzzaman \& Arumugam, 2013; Kwenda \& Holden, 2014; Afrifa \& Padachi, 2016; among others), operating cash flow or capacity to generate internal funds (Fazzari \& Petersen, 1993; Chiou et al., 2006; Baños-Caballero et al., 2009; Nazir \& Afza, 2009; Baños-Caballero et al., 2010; Hill et al., 2010; Gill, 2011; Wasiuzzaman \& Arumugam, 2013; Kwenda \& Holden, 2014; Haron \& Nomran, 2016; among others), and other less represented internal determinants. External factors that have been identified or tested in previous studies include economic conditions, business cycles, ie the growth rate of gross domestic product (Lamberson, 1995; Chiou et al., 2006; Nazir \& Afza, 2009; Baños-Caballero et al., 2010; AL Taleb et al., 2010; Zariyawati et al., 2010; Akinlo, 2012; Manoori \& Muhammad, 2012; Abbadi \& Abbadi, 2013; Russo, 2013; Wasiuzzaman \& Arumugam, 2013; Kwenda \& Holden, 2014; Azeem \& Marsap, 2015; Onaolapo \& Kayjola, 2015), time indicator variables (Baños-Caballero et al., 2009; Rimo \& Panbunyuen, 2010; Russo, 2013; Kwenda \& Holden, 2014), interest rates (Baños-Caballero et al., 2010; Abbadi \& Abbadi, 2013), inflation rate (Zariyawati et al., 2010), etc. There are numerous studies that examine the significance of differences in the working capital management of companies from different industries (Hawawini et al., 1986; Weinraub \& Visscher, 1998; Filbeck \& Krueger, 2005; Chiou et al., 2006; García-Teruel \& MartínezSolano, 2007; Afza \& Nazir, 2008; Lončar \& Ćurak, 2008; Zariyawati et al., 2009; Hill et al., 2010; Gill, 2011; Baños-Caballero et al., 2012a; Aljinović Barać et al., 2013; Koralun-Bereźnicka, 2014; Mongrut et al., 2014; Yazdanfar \& Öhman, 2014; Aktas et al., 2015; Afrifa \& Padachi, 2016; Korent, 2018; among others). Previous studies on working capital determinants have analysed and identified a limited number of significant determinants, the direction and intensity of which, due to the contradiction of their results, and especially the fact that they often differ spatially and temporally, are still being reconsider. If the subject studies are taken as a starting point, the third hypothesis presumes that, in addition to the cash conversion cycle in the previous period, the determinants that significantly affect the cash conversion cycle of companies in selected industries in the Republic of Croatia are the following internal determinants: company size, company growth, return on assets, fixed asset investments and financial leverage, and growth of real gross domestic product as an external determinant.

\section{Method of analysis}

To test the hypotheses, a panel regression model of working capital management determinants was formed. The selection of panel regression analysis is determined by the character of the hypotheses and the nature of the data used, i.e., the variables 
for testing it. The model uses variables used in other similar studies, and their selection is determined by the theoretical basis, their significance in previous studies and the preliminary empirical study, as well as by the availability of data for their calculation. The names, labels, and measurement methods of all variables used to test the hypotheses are set in Table 1. The cash conversion cycle is used as a dependent variable. The variables used as independent variables are the following: cash conversion cycle in the previous period, company size, company growth, net return on assets, fixed asset investments, financial leverage and annual growth of real gross domestic product as an indicator of macroeconomic impact. Variables related to companies are defined for each company-year. The annual growth rate of real gross domestic product varies over time, but is constant for all companies in each period or year.

Table 1: Variables names, labels and methods of measurement

\begin{tabular}{|c|c|}
\hline Variable name and label & Method of measurement of variable \\
\hline Cash conversion cycle (CCC) & $\begin{array}{l}\text { Cash conversion cycle }=(\text { average inventories / operating costs }+ \\
\text { average trade receivables / sales revenue }- \text { average trade paybles } / \\
\text { operating costs }) * 365\end{array}$ \\
\hline Company size & $\begin{array}{l}\text { Company size }(\mathrm{LN} \text { SS })=\ln (\text { sales revenue of company) } \\
\text { Company size categories: small companies }(\mathrm{S}), \text { medium-sized } \\
\text { companies }(\mathrm{M}) \text { and large companies }(\mathrm{L})\end{array}$ \\
\hline Company growth (GRS) & Company growth $=\left(\right.$ sales revenue $_{t}-$ sales revenue $\left._{t-1}\right) /$ sales revenue $\left._{t-1}\right)$ \\
\hline Net return on assets (NROA) & Net return on assets $=$ net profit $/$ total assets \\
\hline Fixed asset investments (FATA) & Fixed assest investments $=$ fixed assets $/$ total assets \\
\hline Financial leverage (LEV) & Financial leverage $=$ total debt $/$ total assets \\
\hline $\begin{array}{l}\text { Annual growth rate of real } \\
\text { gross domestic product } \\
\text { (GDPGR) }\end{array}$ & $\begin{array}{l}\text { The source of data on annual growth rates of real gross domestic } \\
\text { product are the databases of the Croatian Bureau of Statistics. }\end{array}$ \\
\hline
\end{tabular}

Source: Author's work

Theoretical knowledge from the subject area and the results of previous studies indicate the existence of the endogeneity problem. This problem may be due to the existence of reverse causality, bias caused by omitted variables, measurement error, sample selectivity, self-selection, or other reasons (Baltagi, 2005; Wooldridge, 2006). In terms of the former, it is not only the sales, growth, and profitability of a company that can affect the working capital management but also working capital management(Hill et al., 2010). Besides, the presence of unobserved individual effects correlated with independent variables in the model is evident. Both cases were detected in this study and resulted in the correlation of certain independent variables with the model error. Regardless of how it is determined, a dynamic specification of the panel regression model can be used to control the problem of 
endogeneity. The latter is, if the dynamic character of working capital management is taken into account, the most relevant for examining the direction and significance of working capital management determinants. This is in line with the results of the studies conducted by Baños-Caballero et al. (2009), Baños-Caballero et al. (2010), Abbadi \& Abbadi (2013), Russo (2013) and Kwenda \& Holden (2014). Among other things, dynamic panel regression analysis supports the development of a partial target adjustment model that allows the current levels of working capital variables to be explained based on their levels in the previous period and their target levels (Baños-Caballero et al., 2009; Baños-Caballero et al., 2010).

Following the above, the model of working capital management determinants, ie the cash conversion cycle, is tested as a linear dynamic panel model with individual fixed effects according to Expression 1.

$$
\begin{aligned}
C C C_{i t}^{*}= & \beta_{0}+\beta_{1} * L N_{L} S S_{i t}+\beta_{2} * G R S_{i t}+\beta_{3} * N R O A_{i t}+\beta_{4} * F A T A_{i t}+ \\
& \beta_{5} * L E V_{i t}+\beta_{6} * G D P G R_{t}+\varepsilon_{i t}
\end{aligned}
$$

\section{Expression 1}

where the symbol $i$ denotes the company, and the symbol $t$ the year. The cash conversion cycle and the independent variables, i.e., potential determinants, are defined in the previously stated manner, where the $C C C_{i t}{ }^{*}$ represents the target value of the cash conversion cycle for the company $i$ at time $t . \beta_{0}$ represents a constant, and $\varepsilon_{\mathrm{it}}$ symbolizes a random error.

Furthermore, as pointed out earlier, it is assumed that companies seek to adjust their working capital management, i.e., cash conversion cycle, to achieve the target levels of the same. However, since it is assumed that this adjustment is not instantenous because companies face adjustment costs, they adjust their current to target levele according to Expression 2.

$$
C C C_{i t}-C C C_{i, t-1}=\gamma *\left(C C C_{i t}^{*}-C C C_{i, t-1}\right), 0<\gamma<1
$$

\section{Expression 2}

where the $C C C_{i t}$ is the value of the cash conversion cycle for the company $i$ at time $t$, and the $C C C_{i t}{ }^{*}$ is the mentioned target value of the same. The expression $C C C_{i t}{ }^{*}-C C C_{i, t-1}$ represents the adjustment required to to achieve the company's target level of the cash conversion cycle, and the coefficient $\gamma$ measures the speed of adjustment, which is inversely related to the adjustment costs and takes values between 0 and 1 . If $\gamma=1$ then the $C C C_{i t}=C C C_{i t}{ }^{*}$ so the company immediately adjusts its cash conversion cycle to their target level. However, if $\gamma=0$, then $C C C_{i t}$ $=C C C_{i, t-1}$, which indicates that the adjustment costs are so high that the company does not adjust its cash conversion cycle at all and consequently it remains at the same level as in the previous period. 
If the second equation, ie Expression 2, is substituted into the first equation, ie Expression 1, the unobserved heterogeneity, ie time-invariant individual effects specific to each company $\eta_{\mathrm{i}}$, is included, and the following expressions are introduced: $\alpha=\gamma \beta_{0} ; \rho=(1-\gamma) ; \delta_{\mathrm{k}}=\gamma \beta_{\mathrm{k}}$ and $v_{\mathrm{it}}=\gamma \varepsilon_{\mathrm{it}}$, the current value of the cash conversion cycle, ie the regression equation to be tested can be expressed as Expression 3.

$$
\begin{aligned}
C C C_{i t}= & \alpha+\rho * C C C_{i, t-1}+\delta_{1} * L N_{-} S S_{i t}+\delta_{2} * G R S_{i t}+\delta_{3} * N R O A_{i t}+ \\
& \delta_{4} * F A T A_{i t}+\delta_{5} * L E V_{i t}+\delta_{6} * G D P G R_{t}+\eta_{i}+v_{i t}
\end{aligned}
$$

\section{Expression 3}

The defined model is estimated for 9 subsamples of the companies depending on their industry (manufacturing, trade, information and communication) and size (small, medium-sized and large). For the tested model, the statistical significance of the estimate of the parameter $\rho$ is determined for each subsample of the companies. Based on his knowledge and knowledge of the value of the cash conversion cycle for each individual company $i$ in each individual period $t$ and $t-1$, according to Expression 2, the target value of the cash conversion cycle for each individual company $i$ in each individual period $t$ can be determined. Knowing the target value of the cash conversion cycle for each individual company in each individual year allows to determine the deviations of the current value of the company's cash conversion cycle from the same. The absolute value of the relative deviations of the current from the target value enables the evaluation of the working capital management performance of individual companies, as well as their ranking in relation to other companies in the industry.

Finally, the defined model for all subsamples is estimated using a two-step robust Arellano - Bover/Blundell - Bond estimator of linear dynamic panel models. The reason for choosing the Arellano - Bover/Blundell - Bond estimator lies in its suitability, especially since this estimator is designed for panel cases with several time periods and a large number of individual entities (small $\mathrm{T}$, large $\mathrm{N}$ ), with a linear functional relationship, with one dynamic dependent variable that depends on its past realizations and with independent variables that are not strictly exogenous, ie correlated with past and possibly current realizations of random error, then for situations with fixed individual effects implying the existence of unobserved individual heterogeneity, and finally for those with within, but not between heteroskedasticity and autocorrelation (Baum, 2013). Next, the subject estimator is an extension of the Arellano-Bond estimator that corresponds to large autoregressive parameters and a large ratio of panel effect variance, ie unobserved individual effects and idiosyncratic error variance (StataCorp., 2015). In application of this estimator, growth of real gross domestic product is defined as an exogenous variable, cash conversion cycle in the previous period as predetermined, and all remaining variables as endogenous variables. Comparatively, the Arellano - Bover/ 
Blundell - Bond estimator has been used in related studies, for example, by BañosCaballero et al. (2009) and Baños-Caballero et al. (2010), while Russo (2013) and Kwenda \& Holden (2014) used an Arellano - Bond estimator.

\section{Empirical data and analysis}

\subsection{Data sample}

The data sample consists of company-year observations, i.e., data on companies registered in the Republic of Croatia in one of the selected industries, i.e., activity sections according to the National Classification of Activities 2007: C (Manufacturing), G (Wholesale and retail trade; repair of motor vehicles and motorcycles) and $\mathrm{J}$ (information and communication), which persist in the market, have employees, positive sales revenues, operating expenses, assets, capital and reserves, and sum of long-term and short-term liabilities for the period 2008-2015, and are recorded in the Financial Agency database. The data used to conduct the research within this paper are secondary data on companies from the sample and macroeconomic data on the growth of the real gross domestic product. The data needed to calculate the variables at the company level were obtained from the database of the Financial Agency (FINA, 2017), while the macroeconomic data were taken from the databases of the Central Bureau of Statistics (DZS, 2017).

The initially received data sample on all companies from manufacturing, trade and information and communication industries in the Republic of Croatia for the period from 2008 to 2015 consisted of 73,724 companies and 372,871 companyyear observations. Taking into account the criterion of the company persistence in the observed period, in the first step of the final sample creation, the intial sample was balanced using the software package MS Excel and DigDB add-in. After balancing, the sample consisted of 25,076 companies, or 200,608 companyyear observations. In the second step, using the software package Stata 14, the company-year observations without employees (based on working hours), without positive values, ie with non-positive values of sales revenues, operating expenses, assets, capital and reserves or the sum of short-term and long-term liabilities were eliminated from the specified set. After this step, in the sample remained 20,472 companies, ie 132,165 company-year observations. In order to reduce the impact of outliers and allow the adjustment of distribution to normal, in line with some previous studies (Deloof, 2003; García-Teruel \& Martínez-Solano, 2007; BañosCaballero et al., 2012b; Baños-Caballero et al., 2012a; Baños-Caballero et al., 2014; Pais \& Gama, 2015; Lyngstadaas \& Berg, 2016), in the final step of final sample creation for all variables, except for the annual growth of real gross domestic product, $1 \%$ of the minimum and maximum values for each observed variable by subsamples of companies according to their industry and size were eliminated. 
The final unbalanced sample consists of 19,608 companies, or 118,623 companyyear observations. Table 2 shows the structure of the final sample by companies' industry and size, indicating the number of companies and the number of companyyear observations.

Table 2: Sample structure by companies' industry and size (number of companies and company-year observations)

\begin{tabular}{|l|r|r|r|r|}
\hline Industry & \multicolumn{1}{|c|}{$\begin{array}{c}\text { Small } \\
\text { companies }\end{array}$} & $\begin{array}{c}\text { Medium- } \\
\text { sized } \\
\text { companies }\end{array}$ & $\begin{array}{c}\text { Large } \\
\text { companies }\end{array}$ & Total \\
\hline C (Manufacturing) & 5,730 & 493 & 137 & 6,142 \\
\hline G (Wholesale and retail trade; repair & 11,965 & 2,363 & 722 & 35,934 \\
of motor vehicles and motorcycles) & 69,753 & 1,964 & 113 & 12,333 \\
\hline J (Information and communication) & 1,808 & 44 & 540 & 72,257 \\
\hline Total & 10,142 & 192 & 98 & 1,855 \\
& 18,805 & 959 & 268 & 19,432 \\
\hline
\end{tabular}

Source: Author's work

\subsection{Results of empirical analysis}

\subsubsection{Target adjustment model tests results}

The results of the conducted panel regression analysis are given in Table 3. At the significance level of $1 \%$ the cash conversion cycle in the previous period significantly positively affects the cash conversion cycle in the current period in all model estimates, i.e., for all subsamples of companies simultaneously determined by industry and size. The speed of adjustment, ie convergence to the target cash conversion cycle is determined by the coefficient of the speed of adjustment $(\gamma)$, which is equal to the difference between the number 1 and the regression coefficient of the lagged variable of the cash conversion cycle. Specifically, in the manufacturing and information and communications industries, mediumsized companies achieve the highest adjustment coefficients $(\gamma \mathrm{CM}: 0.182 ; \gamma \mathrm{JM}$ : 0.444 ), followed by large companies ( $\gamma \mathrm{CL}: 0.101 ; \gamma \mathrm{JL}: 0.127)$, and finally small companies $(\gamma \mathrm{CS})$. ГJS: 0.120). In the trade section, large companies adjust their cash conversion cycle the fastest ( $\gamma \mathrm{GL}$ : 0.067), medium-sized companies slightly slower ( $\gamma \mathrm{GM}: 0.060)$ and small companies the slowest ( $\gamma \mathrm{GS}: 0.017)$. As evident, the differences in adjustment rates are more pronounced between small companies on the one hand and medium-sized and large companies on the other, than between the latter among themselves. Furthermore, in all three categories of company size, the companies in the information and communication industry are in the lead in 


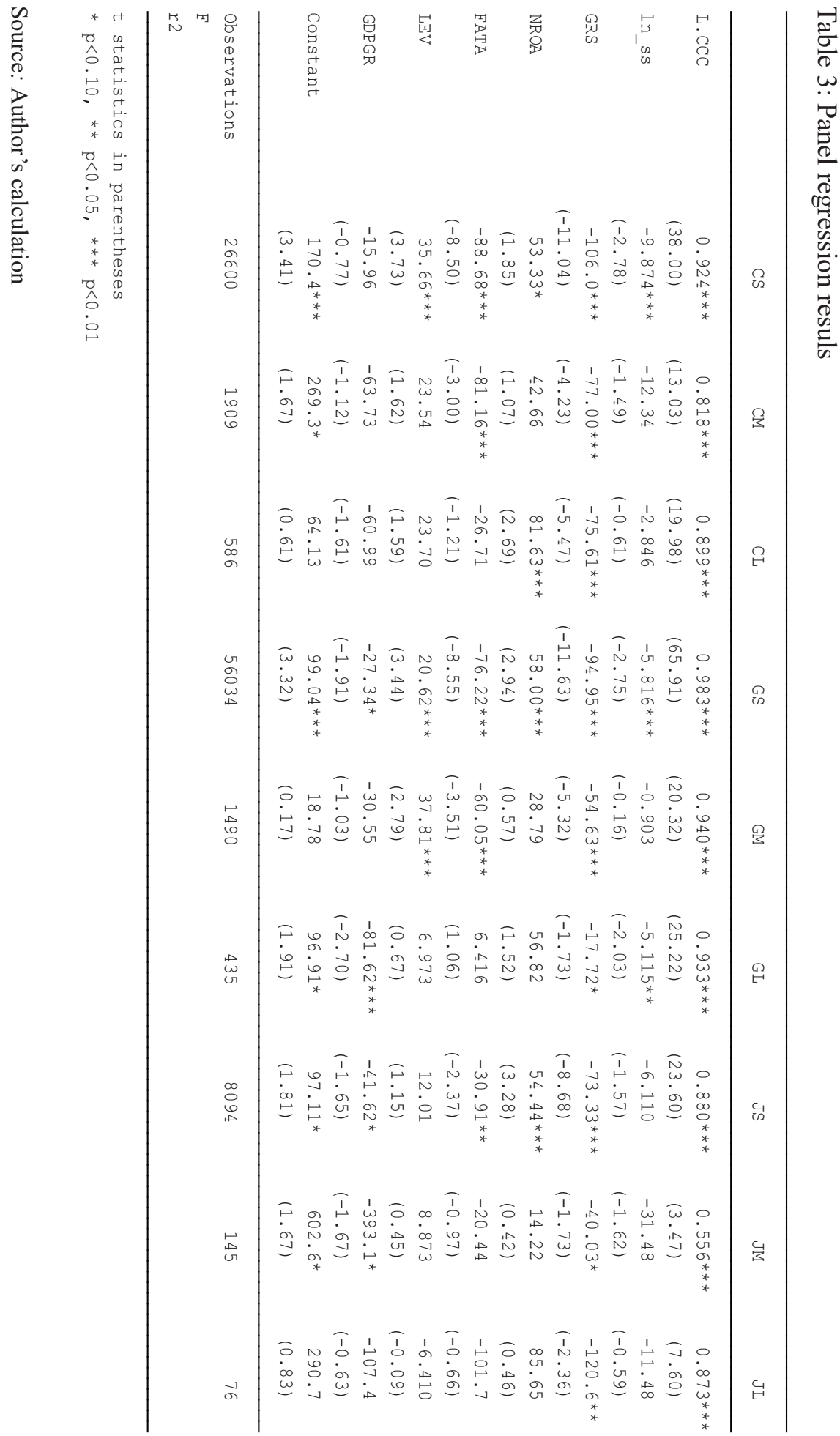


the speed of adjustment of the cash conversion cycle ( $\gamma \mathrm{JS}: 0.120 ; \gamma \mathrm{JM}: 0.444 ; \gamma \mathrm{JL}$ : $0.127)$, followed by companies in manufacturing ( $\gamma \mathrm{CS}: 0.076 ; \gamma \mathrm{CM}: 0.182 ; \gamma \mathrm{CL}$ : 0.101 ), and, finally, companies in trade ( $\gamma \mathrm{GS}: 0.017 ; \gamma \mathrm{GM}: 0.060 ; \gamma \mathrm{GL}: 0.067)$.

If the test results of all potential determinants, not only the lagged cash conversion cycle, are observed, it can be seen that significant estimates of the parameters of the tested cash conversion cycle potential determinants are more present for subsamples of companies in trade than in subsamples of manufacturing and information and communication industries. In the context of subsamples by size, they are more present in subsamples of small companies than is the case for subsamples of medium-sized and large companies from the analyzed industries.

If the subsamples of small companies are compared, in the subsample of small companies in the trade all 7 potential determinants were identified as significant, whereas, in the subsamples of small companies in manufacturing and information and communication industries 6 out of 7 and 5 out of 7 tested potential determinants, respectively, were significant. In the categories of medium-sized and large companies, by the number of significant tested determinants, also, trade is in the lead ( 7 and 4 significant determinants, respectively), followed by manufacturing (3 significant determinants in each) and information and communication industry (3 and 2 significant determinants, respectively).

In particular, for the subsamples of small companies from each of the observed three industries, most tested determinants are unequivocally significant. Exception for manufacturing companies is only the growth of the real gross domestic product, while for small companies in the information and communication industry the company size and financial leverage proved to be insignificant. Compared to subsamples of small companies from a particular industry, subsamples of mediumsized and large companies from the same are characterized by a smaller number of significant estimates of the parameters of the tested determinants of the cash conversion cycle. Significant predictors of the cash conversion cycles of mediumsized and large companies from all three industries were the exclusively lagged cash conversion cycle and company growth. In addition to the above, fixed asset investments and net return on assets have a statistically significant impact on the cash conversion cycles of the medium-sized and large manufacturing companies, respectively, while fixed-asset investments and financial leverage, and company size and growth of the real gross domestic product on the cash conversion cycles of the medium-sized and large companies in trade, respectively. The latter, along with the lagged cash conversion cycle and company growth, is a significant determinant of the cash conversion cycle of medium-sized companies in information and communication industry.

Additionally, in the context of the frequency of significant occurrence in the observed model estimates and subsamples, which is more determined by the 
size category than the predominant industry of the company, completely robust determinants of the cash conversion cycle are the cash conversion cycle in the previous period and company growth. The last ones precede fixed asset investments, the net return on assets, and the growth of the real gross domestic product. The least frequently identified as significant determinants are the company size and financial leverage.

Moreover, in the subsamples in which they proved to be significant, the tested determinants show the same impact on the cash conversion cycles of companies. Besides the lagged cash conversion cycle, the net return on assets and financial leverage has a significant positive effect on the cash conversion cycle and thus,encourage conservative working capital management. On the contrary, company size, company growth, fixed-asset investments, and the growth of the real gross domestic product were detected as significantly negative predictors of the cash conversion cycle.. The latter, accordingly, stimulate more aggressive working capital management.

\subsubsection{Evaluation of working capital management by the new working capital management performance measure}

Given that companies are more or less successful in achieving their target values of the cash conversion cycle in a particular time period, specifically year, their knowledge for each company in each year allows to determine the deviation of current values of the cash conversion cycle from their target values and can serve to evaluate and compare the performance of working capital management strategies of the observed companies. A summary demonstration of the latter for five small companies in manufacturing (class 15.20 Manufacture of footwear), for five small companies in trade (class 47.73 Dispensing chemist in specialized stores) and for five small companies in the information and communication industry (class 62.01 Computer programming activities) for 2015 is shown in Table 4.

Table 4 for each analyzed company shows the values of the cash conversion cycle in 2014 and 2015, as well as the target value of cash conversion cycle for 2015 calculated according to Expression 2 using coefficient of the speed of adjustment for model estimate of small companies from the observed industry $(\gamma \mathrm{CS}: 0.076$, $\gamma \mathrm{GS}: 0.017, \gamma \mathrm{JS}: 0.120)$. Also, the table shows the absolute values of the relative deviations of the current from the target values of the cash conversion cycle and the ranking of companies in accordance with them. 
Dina Korent $\bullet$ Target adjustment model and new working capital management...

Zb. rad. Ekon. fak. Rij. $\cdot 2021 \cdot$ vol. $39 \cdot$ no. $1 \cdot 135-162$

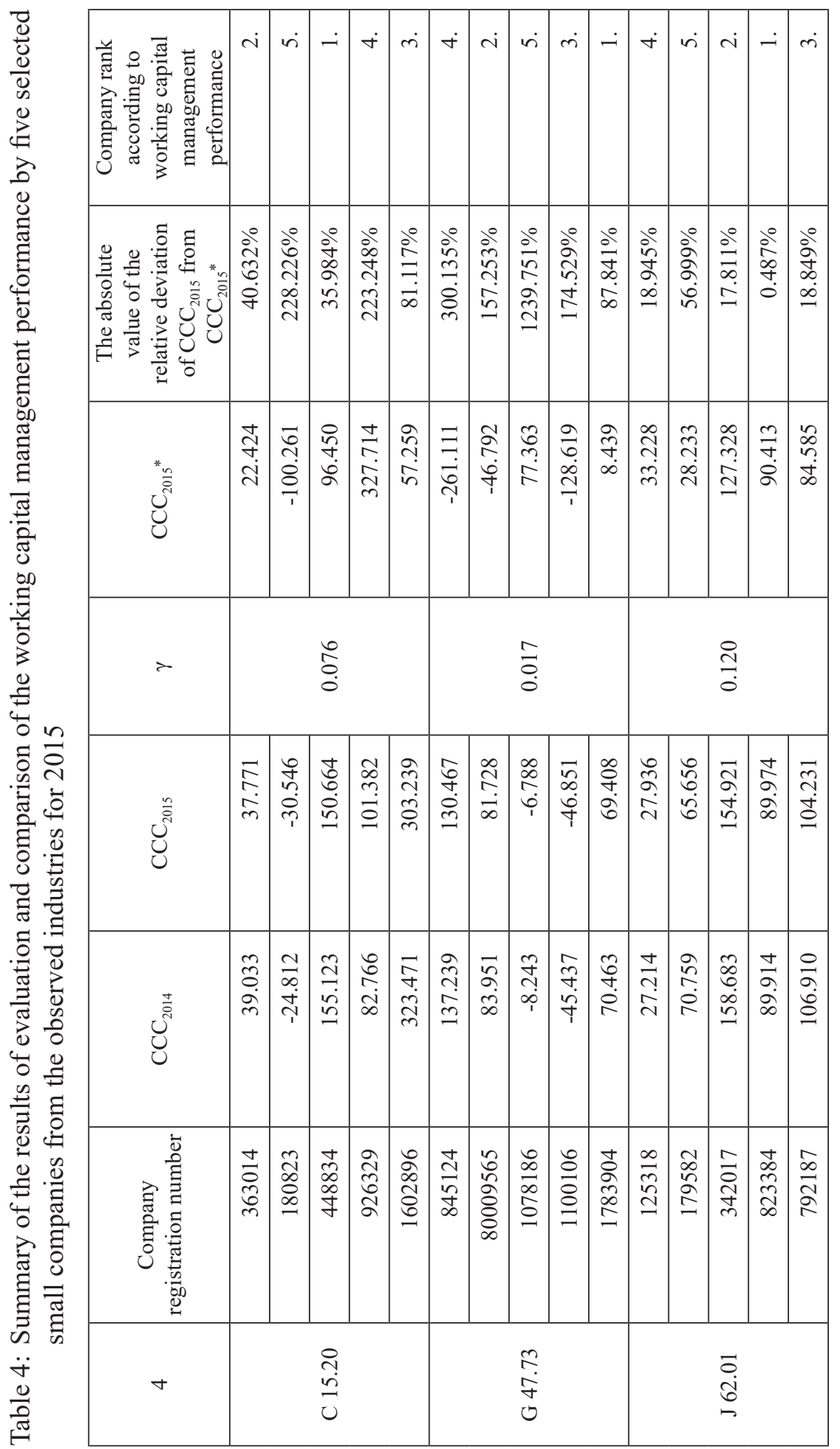

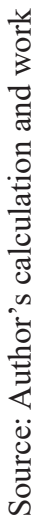




\section{Results and discussion}

The identified significant positive impact of the cash conversion cycle in the current period is consistent with the results of studies conducted by BañosCaballero et al. (2009), Baños-Caballero et al. (2010), Baños-Caballero et al. (2013), Abbadi \& Abbadi (2013) and Kwenda \& Holden (2014), and contrary to the results of the study conducted by Russo (2013), which demonstrates a significantly negative impact of working capital management in the previous period on the same in the current period. Significant estimates of the parameters of lagged cash conversion cycles, and congruent with all previous studies, indicate that the cash conversion cycles of the respective companies depend on their levels in the previous period and on their target levels. In other words, significant estimates of the parameters of lagged cash conversion cycles confirm the dynamic nature of working capital management which implies that companies have target levels of cash conversion cycles and follow their own partial adjustment processes to achieve them. This makes it impossible to reject the first hypothesis.

Estimated coefficients of adjustment rates, regardless of the industry and size of the company, suggest that the speed of adjustment of the cash conversion cycle of the observed companies, except for medium-sized companies from the information and communication industry, is slow, i.e., for this companies the costs of adjusting the cash conversion cycles to their target levels significantly outweigh the costs of being in disequilibrium. Stated is in line with the results of studies conducted by Kwenda \& Holden (2014), but contrary to those of the rapid adjustment found in studies conducted by Baños-Caballero et al. (2009), Baños-Caballero et al. (2010), Abbadi \& Abbadi (2013) and Baños-Caballero et al. (2013). At the same time, congruent with market power, in all three observed industries, medium-sized and large companies achieve higher coefficients of the speed of adjustment $(\gamma)$, i.e. they are characterized by a faster adjustment processes compared to small companies. The order of industries by adjustment rates can also be argued by market power, i.e. by the degree of concentration of industry, which is the highest for information and communication industry (2008-2015 averages: C4: 46.79; C8: 52.95; C50: 73.91; HHI: 821.31), followed by manufacturing (2008-2015 averages: C4: 20.79; C8: 25.94; C50: 48.03; HHI: 268.50) and trade (2008-2015 averages: C4: 11.96; C8: 16.88; C50: 38.26; HHI: 72.45). The presented results indicate that the rate of adjustment to the target cash conversion cycle differ among companies from different industries and size categories, which is why the second hypothesis cannot be rejected.

Further, regardless of the frequency of the significant occurrence of other individual tested determinants in the companies' subsamples, the third hypothesis also cannot be rejected. Accordingly, it can be concluded that in addition to the cash conversion 
cycle in the previous period, the determinants that significantly affect the cash conversion cycle of companies in selected industries in the Republic of Croatia are the following internal determinants: company size, company growth, return on assets, fixed asset investments and financial leverage, and growth of real gross domestic product as an external determinant.

Significantly negative impact of company size, in line with studies conducted by Kieschnick et al. (2006), Baños-Caballero et al. (2010) and Wasiuzzaman \& Arumugam (2013) generally implies that larger companies in the identified subsamples use their size to build better relationships and gain bargaining power in relationships with their suppliers and customers, but also capital market stakeholders, which allows them reduction of working capital investments.

Statistically significant negative predictability of sales growth of companies suggests that higher growth rates of the observed companies, which, due to the fact that the valuation of companies with more growth opportunities depends on these future growth prospects, is characterized by greater information asymmetry and more severe conflicts of interest between creditors and owners (Baños-Caballero et al., 2009), in order to increase the internal resources of the company, result in a reduction of investments in net working capital in a narrower sense. This result is consistent with the results of studies conducted by Baños-Caballero et al. (2009), AL Taleb et al. (2010), Baños-Caballero et al. (2010), Hill et al. (2010), Zariyawati et al. (2010), Gill (2011), Palombini \& Nakamura (2012), Naser et al. (2013), Russo (2013) and Haron \& Nomran (2016).

With exceptions, the diagnosed significantly positive impact of net return on assets on the cash conversion cycle of the analysed companies implies that higher profitability rates result in more conservative working capital management and it is symmetrical to the results of most previous studies (Chiou et al., 2006; Nazir \& Afza, 2009; AL Taleb et al., 2010; Gill, 2011; Manoori \& Muhammad, 2012; Saarani \& Shahadan, 2012a; Abbadi \& Abbadi, 2013; Wasiuzzaman \& Arumugam, 2013; Onaolapo \& Kayjola, 2015). The implication that higher profitability rates result in more conservative working capital management can be explained by the fact that highly profitable companies have sufficient investment funds and are therefore not burdened with efficient working capital management, resulting in higher working capital investments (Chiou et al., 2006; Nazir \& Afza, 2009). The positive relationship also potentially arises from the fact that the monetary value of products in terms of trade receivables is generally higher than the same in terms of trade payables, so each unit of product sold contributes to an increase in working capital needs (Hill et al., 2010).

Further, consistent with the results of previous empirical studies (Fazzari \& Petersen, 1993; Appuhami, 2008; Baños-Caballero et al., 2009; Baños-Caballero et al., 2010; Manoori \& Muhammad, 2012; Saarani \& Shahadan, 2012b; Wasiuzzaman 
\& Arumugam, 2013; Kwenda \& Holden, 2014; Mongrut et al., 2014; Afrifa \& Padachi, 2016), a significant lengthening of the cash conversion cycle is also achieved by a decrease in the company's fixed asset investments. This suggests that fixed assets and working capital compete for the same investment funds (Kwenda \& Holden, 2014), ie that due to financial constraints, fixed asset investments compete with working capital investments for limited available financing (Fazzari \& Petersen, 1993).

Significantly positive predictability of financial leverage, contrary to the pecking order theory, suggests that more indebted companies in the identified subsamples tend to invest more of their capital in the working capital cycle, and that the latter use debts to finance their working capital investments. Stated is in line with the results of studies conducted by Appuhami (2008), Valipour et al. (2012), Naser et al. (2013) and Afrifa \& Padachi (2016), and contradictory to the results of the vast majority of previous empirical studies indicating that the leverage effect is consistently (Chiou et al., 2006; Nazir \& Afza, 2009; Baños-Caballero et al., 2010; AL Taleb et al., 2010; Saarani \& Shahadan, 2012b; Abbadi \& Abbadi, 2013; Wasiuzzaman \& Arumugam, 2013; Kwenda \& Holden, 2014; Azeem \& Marsap, 2015; Onaolapo \& Kayjola, 2015) or dominantly (Akinlo, 2012; Palombini \& Nakamura, 2012; Russo, 2013) significantly negative.

Finally, the detected significantly negative predictability of growth of real gross domestic product is compliant with the results of studies conducted by Chiou et al. (2006) and Manoori \& Muhammad (2012), and contrary to studies conducted by Zariyawati et al. (2010). The results of the former, according to the results of this study, imply that an increase in growth and a decrease in the decline in real gross domestic product result in a shortening of the cash conversion cycle. Conversely, the slowdown in growth and the increase in the decline in real gross domestic product, may casuse certain problems in the sale of inventories and collection of receivables, and as the money supply is small, companies do not get it easily (Chiou et al., 2006). The latter is manifested in higher needs for net operating working capital and an extension of the cash conversion cycle.

Respecting the importance of working capital management, managers must understand the key influencing factors of their companies' working capital investment. The test results of the working capital management impact on the profitability of companies in selected industries in the Republic of Croatia generally pinpoint an aggressive working capital management strategy as profit-maximizing. Generally speaking, financial managers focus on increasing the company size and growth and concurrently reducing financial leverage to manage net operating working capital more aggressively to achieve the target values of cash conversion cycles. These impacts further strengthen the positive direct impacts on the company profitability identified in the previous study. Contrary, although reductions in the companies' size and growth and increases in 
financial leverage result in more conservative working capital management, the possibility of the opposite is provoked. In this case, it is recommended to manage the mentioned determinants in order to avoid their undesirable movements. Forward, due to the decrease in net return on assest and the increase in fixed asset investements and the annual growth rate of real gross domestic product, the proposal is to amortize the negative direct effects of the latter movements by aggressive management. Inverse, given that increasing net return on assets, as well as reducing fixed asset investment and the annual growth rate of real gross domestic product, leads to more conservative working capital management, it is suggested to avoid such practices.

If we refer to the evaluation of working capital management presented in this paper, it is possible to compare the remaining companies analogously by applying the new working capital management performance measure. The accuracy of the evaluation and comparison of working capital management performance can increase by determining the speed of adjustment coefficients for more related or more homogeneous subsamples of companies.

The scientific contribution of the paper is multidimensional. First, unlike most previous empirical studies, this paper adopts a dynamic framework that assumes that companies have optimal or target levels of working capital investment and gradually adjust their current levels of working capital investment over time due to adjustment costs. Through the prism of the above, the paper examines potential determinants of the current levels of cash conversion cycles, identified based on existing literature, in the presence of adjustment costs using dynamic panel data and Arellano - Bover/Blundell - Bond estimator, which allows control for unobserved heterogeneity and endogeneity problems. Studies of this type are generally rare, and has not been conducted in the Republic of Croatia so far. Moreover, the study is of respectable spatial and temporal coverage and expands the range from listed, usually larger companies to, in studies, mainly due to unavailability of data, noticeably less represented, private, and small and medium-sized companies. Given that the paper provides empirical results for a sample of the Croatian companies characterized by a continental governance model, less developed capital market, low level of investor protection and high concentration of ownership, it allows comparison with the results of other studies conducted on samples of companies with different financial systems. Finally, the applicative contribution of the paper is reflected in the provision of guidelines for company managers on how to manage working capital efficiently and in the development of a new measure of working capital management performance that, to various stakeholders, both internal and external, can enable or improve the evaluation and comparison of working capital management performance. The importance of the stated is further emphasized by the current economic situation marked by liquidity tensions of many companies. 


\section{Conclusions}

This paper develops a target adjustment model to investigate determinants that could explain the length of the cash conversion cycle of companies in manufacturing, trade and information and communication industries in the Republic of Croatia for the period 2008-2015. Examining the significance and the speed of the subsamples of the selected companies' adjustment processes of the cash conversion cycles is the focus of interest in this research. Additionally, the paper develops a new measure for evaluating working capital management performance. Consistent with the first hypothesis, the results show that the analyzed companies, due to the presence of adjustment costs, gradually adjust their current cash conversion cycles to the target ones. Besides, this adjustment was slow, which could be explained by the fact that the costs of adjusting to the companies' target cash conversion cycles is higher than the costs of being in disequilibrium. Moreover, the results of this study indicate that the rate of adjustment varies among companies from different industries and size categories, which gives support to the second hypothesis. This can be explained by differences in market power. Apart from lagged cash conversion cycle, whose significantly positive predictability suggests the dynamic nature of working capital management, all other tested potential determinants, although with different robustness, are also statistically significant. Hereof, the third hypothesis cannot be rejected. Managers should, as implied, manage these determinants in order for companies to achieve the target levels of the cash conversion cycles that maximize their profitability and value. Finally, it is suggested that internal and external stakeholders use the developed new measure to improve the evaluation and comparison of the companies' working capital management performance.

Without disputing the scientific contribution of this paper, certain limitations do exist. These include the impossibility of spatial and temporal generalization of identified results, findings and implications, limited possibilities of explaining the identified directions and the significance of the impacts of the observed potential determinants, and detection of reasons for (in)compliance with previous studies results. Furthermore, the unavailability of data and a purely quantitative paradigm results in the restriction that is the omission of potentially significant working capital management factors. Therefore, future research should focus on depreciation and cancellation of established restrictions, especially when conducting comparative research on samples of companies from different countries and conducting qualitative research or combined quantitativequalitative research. 


\section{References}

Abbadi, S. M., Abbadi, R. T. (2013) "The Determinants of Working Capital Requirements in Palestinian Industrial Corporations", International Journal of Economics and Finance, Vol. 5, No. 1, pp. 65-75, https://www.researchgate. net/publication/258048685_The_Determinants_of_Working_Capital_Requirements_in_Palestinian_Industrial_Corporations.

Afrifa, G. A., Padachi, K. (2016) "Working capital level influence on SME profitability", Journal of Small Business and Enterprise Development, Vol. 23, No. 1, pp. 44-63, https://www.emerald.com/insight/content/doi/10.1108/JSBED-012014-0014/full/pdf?title=working-capital-level-influence-on-sme-profitability.

Afza, T., Nazir, M. S. (2008) "Working Capital Approaches and Firm's Returns in Pakistan", Social Sciences, Vol. 1, pp. 25-36, https://www.econstor.eu/bitstream/10419/187978/1/pjcss006.pdf.

Akinlo, O. O. (2012) "Determinants of Working Capital Requirements in Selected Quoted Companies in Nigeria", Journal of African Business, Vol. 13, No. 1, pp. 40-50, https://www.tandfonline.com/doi/pdf/10.1080/15228916.2012.657951? casa_token=cYammUAOUwgAAAAA:pjxstGnIPsdlaKv7wRfqWubYA1Nrpr C7Qa8jjrwDwyWX0NMx_O9M6Pur_-rcg_dT0U6spwO8gggmOg.

Aktas, N., Croci, E., Petmezas, D. (2015) "Is working capital management valueenhancing? Evidence from firm performance and investments", Journal of Corporate Finance, Vol. 30, February 2015, pp. 98-113, https://dro.dur.ac. uk/31420/1/31420.pdf.

Aljinović Barać, Ž., Vuko, T., Vučak, T. (2013) "Effects of working capital management on profitability: evidence from Croatia", in Kandžija, V. and Kumar, A. (eds) 9th International conference Economic integrations, competition and cooperation: accession of the Western Balkan countries to the European Union. Opatija: University of Rijeka, Faculty of Economics, pp. 578-589, https://www. researchgate.net/profile/Vera-Boronenko/publication/321683068_Why_Supporting_Instruments_of_the_Small_Busines_Act_are_not_Widely_Used_by_ the_European_SMEs_The_Case_of_Latvia/links/5a2ab9fba6fdccfbbf850ead/ Why-Supporting-Instruments-of-the-Small-Busines-Act-are-not-Widely-Usedby-the-European-SMEs-The-Case-of-Latvia.pdf\#page $=592$.

AL Taleb, G. et al. (2010) "The Determinants of Effective Working Capital Management Policy: A Case Study on Jordan", Interdisciplinary Journal of Contemporary Research in Business, Vol. 2, No. 4, pp. 248-264.

Appuhami, B. A. R. (2008) “The Impact of Firms' Capital Expenditure On Working Capital Management: An Empirical Study Across Industries in Thailand", International Management Review, Vol. 4, No. 1, pp. 1-10, https://www.proquest. com/docview/195578526/fulltextPDF/81C9218BAF944EC5PQ/1?account $\mathrm{id}=202211$. 
Azeem, M. M., Marsap, A. (2015) "Determinant Factors and Working Capital Requirement", International Journal of Economics and Finance, Vol. 7, No. 2, pp. 280-292, https://pdfs.semanticscholar.org/4e9a/baea1b0963ebdb367e4d02f36392a67e4b75.pdf.

Baltagi, B. H. (2005) Econometric Analysis of Panel Data. 3rd edn. Chichester, West Sussex: John Wiley \& Sons, Ltd.

Baños-Caballero, S., García-Teruel, P. J., Martínez-Solano, P. (2009) "How do market imperfections affect working capital management?", Working papers= Documentos de trabajo: Serie EC (Instituto Valenciano de Investigaciones Económicas), Vol. 14, No. 1, pp. 3-25, http://www.ivie.es/downloads/docs/ wpasec/wpasec-2009-14.pdf.

Baños-Caballero, S., García-Teruel, P. J., Martínez-Solano, P. (2012a) "How does working capital management affect the profitability of Spanish SMEs?", Small Business Economics, Vol. 39, No. 2, pp. 517-529, https://link.springer.com/content/pdf/10.1007/s11187-011-9317-8.pdf.

Baños-Caballero, S., García-Teruel, P. J., Martínez-Solano, P. (2012b) "Working capital requirement financing and Spanish SMEs performance", Fundación de Estudios Financieros, pp. 5-23, https://www.ieaf.es/images/premios-de-investigacion/premios-2012/WORKING.pdf.

Baños-Caballero, S., García-Teruel, P. J., Martínez-Solano, P. (2013) “The speed of adjustment in working capital requirement", The European Journal of Finance, Vol. 19, No. 10, pp. 978-992, https://www.tandfonline.com/doi/pdf/10.1080/13 51847X.2012.691889?casa_token=U9xKhetExrwAAAAA:a94QjCbudMYIpX oS7e0d88WccdXQiQ3k9UA0TWNUAUpeeerj-9NppsLL853nHBEJFjqbeJu37iKqjw.

Baños-Caballero, S., García-Teruel, P. J., Martínez-Solano, P. (2014) "Working capital management, corporate performance, and financial constraints", Journal of Business Research, Vol. 67, No. 3, pp. 332-338, http://www.aeca1.org/pub/ on_line/comunicaciones_xvicongresoaeca/cd/106b.pdf.

Baños-Caballero, S., Martínez-Solano, P., García-Teruel, P. J. (2010) “Working capital management in SMEs", Accounting and Finance, Vol. 50, No. 457, pp. 511-527, https://onlinelibrary.wiley.com/doi/pdf/10.1111/j.1467-629X.2009. 00331.x?casa_token=QXNAq9--SwkAAAAA\%3AZ10TJsFf7QWrAq1jpjsMX vAu1lkx8UZȲ2XSa-_bLkj4-iMiznRc1nmPqrdqXhUx53ueRENadaLTx7vwr.

Baum, C. F. (2013) Dynamic Panel Data estimators; EC 823: Applied Econometrics. Course material. Boston College, http://fmwww.bc.edu/EC-C/S2013/823/ EC823.S2013.nn05.slides.pdf.

Chiou, J.-R., Cheng, L., Wu, H.-W. (2006) "The Determinants of Working Capital Management", The Journal of American Academy of Business, Vol. 10, No. 1, pp. 149-156. 
Deloof, M. (2003) "Does working capital management affect profitability of Belgian firms?", Journal of Business Finance and Accounting, Vol. 30, No. 3-4, pp. 573-587, https://onlinelibrary.wiley.com/doi/pdf/10.1111/1468-5957.00008? casa_token=yRMAw77FtlgAAAAA:pgj6pNpYnim2AGVd0NBp0F-xEjwOT0JGj2QPb1o8ZLHMo9tQ4NcoDG7DVwL9u0m YfgHWVUaiVSO4EN7N.

DZS (2017) Strukturne-poslovne statistike poduzeća, Priopćenje. Zagreb. Available at https://www.dzs.hr/Hrv_Eng/publication/2017/15-01-01_01_2017.htm, Accessed 8 June 2017.

Fazzari, S. M., Petersen, B. C. (1993) "Working Capital and Fixed Investment: New Evidence on Financing Constraints", The RAND Journal of Economics, Vol. 24, No. 3, pp. 328-342, https://www.researchgate.net/profile/Steven-Fazzari-2/publication/24048817_Working_Capital_and_Fixed_Investment_New_Evidence_ on_Financing_Constraints/links/00b4953c82135943f0000000/ Working-Capital-and-Fixed-Investment-New-Evidence-on-Financing-Constraints.pdf.

Filbeck, G., Krueger, T. M. (2005) "An Analysis of Working Capital Management Results Across Industries", American Journal of Business, Vol. 20, No. 2, pp. 1120, https://www.emerald.com/insight/content/doi/10.1108/19355181200500007/ full/pdf?casa_token=uRgymRR0Gd8AAAAA:LulOvIC-JL1zZrqlnE8CyT19wuYwRyiLB-SVrs-5r3KxS-8KfAPHCu44MYnhuHAK1c0C0lhRQgp_5ZEskF 2yNDiE9JiA0o8L-HnOizaxEHOp6dTR6gAm.

FINA (2017) Baza podataka FINA-e. Kupljeni podaci o poduzećima iz odabranih djelatnosti. Zagreb.

Ganesan, V. (2007) "An analysis of working capital management efficiency in telecommunication equipment industry", Rivier academic journal, Vol. 3, No. 2, pp. 1-10, http://citeseerx.ist.psu.edu/viewdoc/download?doi=10.1.1.566.1800\& rep=rep1\&type $=$ pdf.

García-Teruel, P. J., Martínez-Solano, P. (2007) "Effects of working capital management on SME profitability", International Journal of Managerial Finance, Vol. 3, No. 2, pp. 164-177, https://www.emerald.com/insight/content/ doi/10.1108/17439130710738718/full/pdf?title=effects-of-working-capitalmanagement-on-sme-profitability.

Gill, A. (2011) "Factors that influence working capital requirements in Canada", Economics and Finance Review, Vol. 1, No. 3, pp. 30-40, https://www.researchgate.net/profile/Amarjit-Gill/publication/ 268350639_Factors_that_influence_working_capital_requirements_in_Canada/ links/55ca327808aeb975674a4668/Factors-that-influence-working-capital-requirements-in-Canada.pdf.

Haron, R., Nomran, N. M. (2016) "Determinants of Working Capital Management Before, During and After The Global Financial Crisis of 2008: Evidence From 
Malaysia", The Journal of Developing Areas, Vol. 50, No. 5, pp. 461-468, http://irep.iium.edu.my/50858/1/BNote17RazaliHaronEACOMPLETED.pdf.

Hawawini, G., Viallet, C., Vora, A. (1986) "Industry influence on corporate working capital decisions", Sloan Management Review, Vol. 27, No. 4, pp. 15-24, https://mpra.ub.uni-muenchen.de/44894/1/MPRA_paper_44894.pdf.

Hill, M. D., Kelly, G. W., Highfield, M. J. (2010) "Net Operating Working Capital Behavior: A First Look”, Financial Management, Vol. 39, No. 2, pp. 783-805, h t t p s://onlinelibrary.wiley.com/doi/pdf/10.1111/j. 1755-053X.2010.01092.x?casa_token=BGR6ALP253MAAAAA:Mqe9TeSSH phicKXROcf-XppwPjiilKiDZ7̄ps-dkwWs2nrsWZmmmCD-QTxylQPJ5im_ dYBCTrVZavnI7e.

Kieschnick, R., LaPlante, M., Moussawi, R. (2006) "Corporate working capital management: determinants and consequences", International Journal of Managerial Finance, Vol. 3, No. 2, pp. 164-177, https://www.researchgate.net/profile/ Robert-Kieschnick/publication/242506805_Corporate_working_capital_management_Determinants_and_Consequences/links/54c8f3c30cf238bb7d0ea5c5/ Corporate-working-capital-management-Determinants-and-Consequences.pdf

Koralun-Bereźnicka, J. (2014) "On the Relative Importance of Corporate Working Capital Determinants: Findings from the EU Countries", Contemporary Economics, Vol. 8, No. 4, pp. 415-434, https://www.econstor.eu/bitstream/10419/ 141892/1/825958865.pdf.

Korent, D. (2018) Identifikacija odrednica upravljanja obrtnim kapitalom u funkciji povećanja profitabilnosti poduzeća u odabranim djelatnostima u Republici Hrvatskoj. Doktorski rad. Zagreb: Ekonomski fakultet Zagreb.

Kwenda, F., Holden, M. (2014) "Determinants of Working Capital Investment in South Africa: Evidence from Selected JSE-Listed Firms", Journal of Economics and Behavioral Studies, Vol. 6, No. 7, pp. 569-580, https://ojs. amhinternational.com/index.php/jebs/article/view/518/518.

Lamberson, M. (1995) "Changes in Working Capital of Small Firms in Relation to Changes in Economic Activity", American Journal of Business, Vol. 10, No. 2, pp. 45-50, https://www.emerald.com/insight/content/doi/10.1108/ $19355181199500015 /$ full/pdf?title=changes-in-working-capital-of-small-firmsin-relation-to-changes-in-economic-activity.

Lee, C. F., Wu, C. (1988) "Expectation formation and financial ratio adjustment processes", The Accounting Review, Vol. 63, No. 2, pp. 292-306, https://www. ideals.illinois.edu/bitstream/handle/2142/28908/expectationforma1395leec. pdf? sequence $=1$ \&isAllowed $=\mathrm{y}$.

Lončar, S., Ćurak, M. (2008) "Efficiency of working capital management and its influence on the profitablity - the case of Croatian companies", Journal of International Research Publications: Economy \& Business, Vol. 2, pp. 246-265. 
Lyngstadaas, H., Berg, T. (2016) "Working capital management: evidence from Norway", International Journal of Managerial Finance, Vol. 12, No. 3, pp. 295-313, https://www.emerald.com/insight/content/doi/10.1108/IJMF-012016-0012/full/pdf?title=working-capital-management-evidence-from-norway.

Manoori, E., Muhammad, D. (2012) "Determinants of working capital management: Case of Singapore firms", Research Journal of Finance and Accounting, Vol. 3, No. 11, pp. 15-24, http://citeseerx.ist.psu.edu/viewdoc/download?doi=1 $0.1 .1 .856 .4142 \&$ rep $=$ rep $1 \&$ type $=$ pdf.

Mongrut, S. et al. (2014) "Determinants of Working Capital Management in Latin American Companies", Innovar, Vol. 24, No. 51, pp. 5-18, http://www.ub.edu/ iafi/Recerca/Seminaris/Papersamuel.pdf.

Moss, J. D., Stine, B. (1993) "Cash conversion cycle and firm size: A study of retail firms", Managerial Finance, Vol. 19, No. 8, pp. 25-34, https://www.academia. edu/23645809/CASH_CONVERSION_CYCLE_AND_FIRM_SIZE_A_ STUDY_OF_RETAIL_FIRMS.

Nadiri, M. I. (1969) “The Determinants of Trade Credit in the U.S. Total Manufacturing Sector", Econometrica, Vol. 37, No. 3, pp. 408-432, https://www. researchgate.net/profile/M-Nadiri/publication/4894382_The_Determinants_of_ Trade_Credit_in_the_US_Total_Manufacturing_Sector/ links/57d85ae508ae6399a3992594/The-Determinants-of-Trade-Credit-in-theUS-Total-Manufacturing-Sector.pdf.

Naser, K., Nuseibeh, R., Al-Hadeya, A. (2013) "Factors Influencing Corporate Working Capital Management: Evidence from an Emerging Economy", Journal of Contemporary Issues in Business Research, Vol. 2, No. 1, pp. 11-30, https:// citeseerx.ist.psu.edu/viewdoc/download?doi=10.1.1.278.4754\&rep=rep1\&type $=$ pdf.

Nazir, M. S., Afza, T. (2009) "Working Capital Requirements and the Determining Factors in Pakistan", IUP Journal of Applied Finance, Vol. 15, No. 4, pp. 28-38, https://www.researchgate.net/profile/Talat-Afza-2/publication/228618942_ Working_Capital_Requirements_and_the_Determining_Factors_in_Pakistan/ links/09e4150c06b3e1db5e000000/Working-Capital-Requirements-and-theDetermining-Factors-in-Pakistan.pdf.

Onaolapo, A. A., Kayjola, S. O. (2015) "What are the Determinants of Working Capital Requirements of Nigerian Firms?", Research Journal of Finance and Accounting, Vol. 6, No. 6, pp. 118-128., https://core.ac.uk/reader/234630590.

Pais, M. A., Gama, P. M. (2015) "Working capital management and SMEs profitability: Portuguese evidence", International Journal of Managerial Finance, Vol. 11, No. 3, pp. 341-358, https:/www.emerald.com/insight/content/ doi/10.1108/IJMF-11-2014-0170/full/pdf?title=working-capital-managementand-smes-profitability-portuguese-evidence. 
Palombini, N. V. N., Nakamura, W. T. (2012) "Key factors in working capital management in the Brazilian market", Revista de Administração de Empresas, Vol. 52, No. 1, pp. 55-70, https://www.scielo.br/j/rae/a/YT7WszFRfLK4S8cnWSF8 $5 \mathrm{rQ} /$ ?lang=en.

Peles, Y. C., Schneller, M. I. (1989) "The duration of the adjustment process of financial ratios", The Review of Economics and Statistics, Vol. 71, No. 3, pp. 527-532, https://www.jstor.org/stable/1926912, https://www.jstor.org/stable/1926912.

Raheman, A., Nasr, M. (2007) "Working Capital Management And Profitability - Case Of Pakistani Firms", International Review of Business Research Papers, Vol. 3, No. 1, pp. 279-300, https://www.researchgate.net/profile/Mohamed-Nasr-22/publication/228727444_Working_capital_management_and_profitability-case_of_Pakistani_Firms/links/0c960523758d23d0e1000000/Working-capital-managementand-profitability-case-of-Pakistani-Firms.pdf.

Rimo, A., Panbunyuen, P. (2010) The effect of company characteristics on working capital management A quantitative study of Swedish listed companies. Master thesis. Umeå University, Umeå School of Business, Economics and Statistics, https://docplayer.net/6719852-The-effect-of-company-characteristics-on-working-capital-management.html.

Russo, J. F. T. B. (2013) The working capital management: the determinants and the effect on profitability: Evidence from Portuguese SMEs. Master Thesis. ISCTE - Instituto Universitário de Lisboa., https://repositorio.iscte-iul.pt/bitstream/10071/8554/1/Thesis_Russo_J_Final.pdf.

Saarani, A. N., Shahadan, F. (2012a) "Analyzing the Validity of Working Capital Determinant Factors of Enterprise 50 (E50) Firms in Malaysia using Partial Least Square-Structural Equation Modeling", in Proceeding Perkem VII. Ipoh, Perak: Transformasi Ekonomi dan Sosial Ke Arah Negara Maju, pp. 466-472, https://www.ukm.my/fep/perkem/pdf/perkemVII/PKEM2012_2C2.pdf.

Saarani, A. N., Shahadan, F. (2012b) "The Determinant Factors of Working Capital Requirements for Enterprise 50 (E50) Firms in Malaysia: Analysis Using Structural Equation Modelling", Social Sciences and Scientific Studies, Vol. 5, No. 2, pp. 52-66, https://www.academia.edu/2038148/The_Determinant_Factors_of_ Working_Capital_Requirements_for_Enterprise_50_E50_Firms_in_Malaysia_ Analysis_Using_Structural_Equation_Modelling.

StataCorp. (2015) STATA Longitudinal-Data/Panel-Data Reference Manual, Release 14. Stata Press. Texas: Stata Press.

Valipour, H., Moradi, J., Farsi, F. D. (2012) “The Impact of Company Characteristics on Working Capital Management", Journal of Applied Finance \& Banking, Vol. 2, No. 1, pp. 105-125, http://www.scienpress.com/Upload/JAFB/Vol\%20 2_1_5.pdf.

Wasiuzzaman, S., Arumugam, V. C. (2013) "Determinants of Working Capital Investment: A Study of Malaysian Public Listed Firms”, Australasian Accounting 
Business \& Finance Journal, Vol. 7, No. 2, pp. 49-69, https://ro.uow.edu.au/ cgi/viewcontent.cgi?referer=https://scholar.google.hr/\&httpsredir=1\&article=1 $436 \&$ context $=$ aabfj.

Weinraub, J. H., Visscher, S. (1998) "Industry practice relating to aggressive conservative working capital policies", Journal of Financial and Strategic Decisions, Vol. 11, No. 2, pp. 11-18, https://www.researchgate.net/publication/237607242_Industry_practice_relating_to_aggressive_conservative_working_capital_policies.

Wooldridge, J. M. (2006) Introductory Econometrics: A Modern Approach. 2rd ed. Thomson South-Western.

Yazdanfar, D., Öhman, P. (2014) "The impact of cash conversion cycle on firm profitability: An empirical study based on Swedish data", International Journal of Managerial Finance, Vol. 10, No. 4, pp. 442-452, https://www.emerald.com/ insight/content/doi/10.1108/IJMF-12-2013-0137/full/pdf?title=the-impact-ofcash-conversion-cycle-on-firm-profitability-an-empirical-study-based-on-swedish-data.

Zariyawati, M. A. et al. (2009) "Working capital management and corporate performance: Case of Malaysia", Journal of Modern Accounting and Auditing, Vol. 5, No. 11, pp. 47-54, https://www.researchgate.net/publication/259704839 Working_Capital_Management_and_Corporate_Performance_Case_of_Malaysia. Zariyawati, M. A. et al. (2010) "Determinants of Working Capital Management: Evidence from Malaysia", in Financial Theory and Engineering (ICFTE), 2010 International Conference on Financial Theory and Engineering. Dubai: IEEE, pp. 190-194, https://www.researchgate.net/publication/241169568_Determinants_of_working_capital_management_Evidence_from_Malaysia. 


\title{
Model ciljne prilagodbe i nova mjera uspješnosti upravljanja obrtnim kapitalom: Slučaj Hrvatske
}

\author{
Dina Korent ${ }^{1}$
}

\begin{abstract}
Sažetak
U radu je razvijen dinamički panel model ciljne prilagodbe kako bi se istražile odrednice ciklusa konverzije novca prerađivačkih, trgovinskih i poduzeća u djelatnosti Informacije i komunikacije u Republici Hrvatskoj za razdoblje 2008.2015. Pritom je naglasak na ispitivanju signifikantnosti te brzina procesa prilagodbi ciklusa konverzije novca poduzoraka promatranih poduzeća po djelatnosti i veličini. Rezultati pokazuju da promatrana poduzeća, zbog troškova prilagodbe, postupno prilagođavaju svoje trenutne cikluse konverzije novca ciljnima. Uz to, utvrđeno je da je ta prilagodba spora, što se može objasniti pretežnošću troškova prilagodbe nad troškovima ostanka u neravnoteži. Dodatno, rezultati ovog istraživanja ukazuju da se brzina prilagodbe razlikuje među poduzećima iz različitih djelatnosti $i$ kategorija veličine. Navedeno se može objasniti razlikama u tržišnoj moći među istima, koja poduzećima omogućava lakše promjene komponenata ciklusa konverzije novca, te, shodno tome, bržu konvergenciju njihovim ciljnim razinama. Uz zakašnjeli ciklus konverzije novca, testirane potencijalne odrednice koje signifikantno utječu na cikluse konverzije novca hrvatskih poduzeća u odabranim industrijama, premda s različitom robusnošću, su i veličina poduzeća, rast poduzeća, neto prinos na imovinu, ulaganja u fiksnu imovinu, financijska poluga i rast realnog bruto domaćeg proizvoda. Konačno, rad prezentira novu mjeru za vrednovanje uspješnosti upravljanja obrtnim kapitalom.
\end{abstract}

Ključne riječi: upravljanje obrtnim kapitalom, model ciljne prilagodbe, odrednice, mjera uspješnosti, Hrvatska

JEL klasifikacija: $G 3$

${ }^{1}$ Dr. sc., Viša asistentica/poslijedoktorandica, Fakultet organizacije i informatike, Pavlinska 2, 42000 Varaždin, Sveučilište u Zagrebu - Hrvatska. Znanstveni interes: poslovne financije, upravljanje obrtnim kapitalom, budžetiranje kapitala, struktura kapitala, poslovno planiranje. Tel.:+38598160 2295. E-mail: dina.korent@foi.unizg.hr.https://www.foi.unizg.hr/hr/djelatnici/ dina.korent. 